Macaulay and Son 



\section{Macaulay and Son}

ARCHITECTS OF IMPERIAL BRITAIN

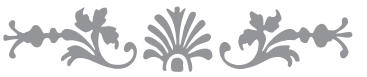

CATHERINE HALL 
Copyright (C 2012 Catherine Hall

All rights reserved. This book may not be reproduced in whole or in part, in any form (beyond that copying permitted by Sections 107 and 108 of the U.S. Copyright Law and except by reviewers for the public press) without written permission from the publishers.

For information about this and other Yale University Press publications, please contact:

U.S. Office: sales.press@yale.edu www.yalebooks.com

Europe Office: sales @yaleup.co.uk www.yalebooks.co.uk

Set in Minion Pro by IDSUK (DataConnection) Ltd

Printed in Great Britain by TJ International Ltd, Padstow, Cornwall

Library of Congress Cataloging-in-Publication Data

Hall, Catherine, 1946

Macaulay and son : architects of imperial Britain/Catherine Hall. p. $\mathrm{cm}$.

ISBN 978-0-300-16023-9 (cl : alk. paper)

1. Macaulay, Thomas Babington Macaulay, Baron, 1800-1859. 2. Historians-Great

Britain-Biography. 3. Statesmen-Great Britain-Biography. 4. Authors,

English-19th century-Biography. 5. Macaulay, Zachary, 1768-1838.

6. Abolitionists-Great Britain-Biography. I. Title.

DA3.M3H267 2012

$941.081092^{\prime} 2-\mathrm{dc} 23$

[B]

A catalogue record for this book is available from the British Library.

$\begin{array}{llllllllll}10 & 9 & 8 & 7 & 6 & 5 & 4 & 3 & 2 & 1\end{array}$ 
For Margaret and Stuart 
